УДК 372.832

DOI:

Наталія Жидкова, кандидат педагогічних наук, учитель Менської гімназї Менської міської ради Чернігівської обл.

\title{
ПРАКТИЧНІ ЗАНЯТТЯ З СУСПІЛЬСТВОЗНАВСТВА - ТВОРЧА МАЙСТЕРНЯ КОМПЕТЕНТНОГО УЧНЯ
}

У статті розкрито окремі аспекти понятійно-категоріального апарату практичних занять 3 правознавства як творчої майстерні компетентного учня. 3'ясовано, щзо творчість учнів розвивається під час розв 'язання проблемних завдань з використанням засобів та прийомів розвитку емоційного та логічного мислення. Проведений аналіз змісту практичних занять дозволив визначити ознаки, щуо вирізняють їх з поміж інших уроків. В основі запропонованої етапної моделі практичного заняття, спрямованої на розвиток творчості учнів, - пошук ефективного способу розв 'язання проблеми у спільній діяльності класу.

Ключові слова: практичні заняття; суспільствознавча галузь освіти; навчання історії та правознавства; творчість учнів; компетентність; модель практичного заняття; проблемне завдання.

Табл. 2. Літ. 17.

Nataliya Zhydkova, Ph.D.(Pedagogy) Teacher of Menska Gymnasium, Menska City Council, Chernihiv Region

\section{PRACTICAL EXERCISES OF SOCIAL STUDIES - CREATIVE WORKSHOPS OF COMPETENT STUDENTS}

The author describes the importance of the development of creativity, which has a positive impact on the successful life with individually oriented and competence approach. The author places so much emphasis on the analysis of conceptual questions of practical exercises of Social Studies as creative workshops of competent students. The article notes the importance of the development of conceptual thinking, skills for analyzing the events and phenomena of life and educational situations. A mentally creative innovator is flexible, in depth and broadmindedness, an in affective way of resolving problems. In that process, it is important to develop emotional and logical thinking of pupils, fantasies, their abilities to imagine by using curricular and cross-curricular links, verbal educational and figurative methods. The variety of methods, techniques, teaching facilities are contributed to the motivation of students.

The importance of the practical exercise to the development of creative work is determined. This is an education of workshop of the enhance abilities and skills, enrichment of the lessons learned by original methods of solutions system-inherent challenges in the process of creative and cognitive activities.

The model watershed-course of the practical exercises provides the development of a problematic situation, the formulation of the thematic, crucial and semantic problems, the mainstream of the knowledge and skills, formulating assumption, purposes, plans, choose ways of achieving aims (introductory part), the creative-search activities, the solutions of the system-inherent challenges, the formation of an unique method activities (each lesson), the responses and analyses of the results, the auto-evaluation and self-evaluation (concluding part).

The students' creative activity allows a considerable degree of freedom, the coordination and advising of the teachers' function to joint activities of the form and characterized by a creative approach to training, the establishment of a dynamic instruction.

Keywords: practical exercise; Social Pupils curriculum; the c pupils' reativity; the competence of pupils; the education of the history and law, the model of practical exercise; the problem task.

П остановка проблеми. В умовах інформаційного суспільства актуальним в освітньому середовищі $є$ підготовка компетентної та творчої особистості для успішної життєдіяльності. Відповідно до суспільних потреб у шкільному освітньому середовищі потрібно сформувати вміння творчо та ефективно розв' язувати життєві та предметні проблеми. Це зумовлює у навчанні предметів суспільствознавчої галузі освіти необхідність розвитку гнучкості мислення школярів, здатності займати активну громадянську позицію та бути відповідальним у ставленні до природи, свого здоров'я і життя, а також життя інших людей.

У 1996 р. у доповіді ЮНЕСКО було сформовано чотири ціннісні напрями, за якими має розвиватися освіта XXI ст. Це глобальні компетентності: уміння людей жити разом (знання і розуміння культури, традицій, цінностей інших народів, мирне співіснування народів); уміння вчитися (здобуття академічної освіти 3 поглибленим вивченням спеціальних предметів); уміння діяти (можливість людини в непередбачуваних обставинах працювати в 


\section{ПРАКТИЧНІЗАНЯТТЯ ЗСУСПІЛЬСВОЗНАВСТВА-ТВОРЧА МАЙСТЕРНЯ КОМПЕТЕНТНОГОУЧНЯ}

команді); уміння бути (уміння, навички для повної реалізації природних задатків людини) $[15,5]$. Такі вміння потребують використання в освіті особистісно-зорієнтованого, компетентнісного, діяльнісного та метапредметного підходів.

Зазначимо, що одним із шляхів формування в учнів глобальних компетентностей, що сприяє їх особистісному розвитку, є реалізація творчого компоненту компетентнісного навчання. Загалом процес навчання спрямований на формування системи компетентностей: ключової, міжпредметної та предметної (галузева). Кожна компетентність $є$ динамічною комбінацією знань, умінь, навичок, способів мислення, поглядів, цінностей, особистісних якостей і допомагає успішно соціалізуватися та проводити навчальну діяльність.

Базовими предметами суспільствознавчої галузі освіти у підлітковому віці $є$ історія та правознавство. Предметна історична компетентність учнів формується у системі хронологічної, просторової, інформаційної, логічної та аксіологічної компетенцій. Складниками правової предметної компетентності є: інформаційна або когнітивна (правові знання, логічні вміння, пов'язані $з$ їх збиранням, використанням, поширенням), логічна, аксіологічна або ціннісномотиваційна (розуміння значення держави і права, мотиви правомірної поведінки, особисте емоційноціннісне ставлення до певних правових фактів на основі власних ціннісних орієнтацій), практикоповедінкова або діяльнісно-процесуальна (уміння використовувати правові знання, логічні та мовленнєві вміння для виконання завдань, розв'язання проблем у правовому полі, формування способу дій) компетенції.

Зазначимо, що діяльнісна складова компетентнісного навчання містить рівні: репродуктивний, перетворювальний та творчий (як можливості створити нове, запропонувати нові підходи та способи розв'язання проблеми, формування нових цінностей та ін.). Більшість дослідників, характеризуючи компетентності, не значну увагу приділяють творчому компоненту навчання. Одним із занять, під час якого учні можуть творчо реалізувати компетенції, спрямовані на розвиток творчих здібностей, $-\epsilon$ практичні заняття.

Аналіз основних досліджень. Практичні заняття 3 історії та правознавства у різних дискурсах стали предметом досліджень К. Баханова, А. Будас, В. Власова, Є. Вяземського, О. Галай, М. Короткової, І. Костюк, Ю. Малієнко, С. Микитюка, О. Пометун, Т. Ремех, Л. Рябовол, О. Стрелової Г. Фреймана, Н. Яременко та ін. Розвитку творчих здібностей учнів приділено увагу в роботах І. Дичківської, С. Ільїна, В. Моляко, П. Мороза, А. Хуторського.

Метою статті $€$ теоретичне обгрунтування моделі практичного заняття з суспільствознавчих предметів як творчої майстерні компетентного учня.

Виклад основного матеріалу. Розкриваючи зміст статті, зупинимося на понятті творчості, його етапах, рівнях, складових та методах розвитку творчих здібностей. У філософському дискурсі творчість є продуктивною діяльністю за мірками свободи та оновлення, коли детермінація зовнішньої активності змінюється внутрішньою самовизначеністю. 3 психологічного підходу творчість пов'язана 3 самореалізацією індивідуальності, чинниками уяви, інтуїції, ейдетичності (ідейно-образного відчуття закономірностей), з евристичним мисленням [17, 630]. У педагогічній літературі творчість пояснюється як продуктивна людська діяльність, здатна породжувати якісно нові матеріальні та духовні ияінності суспільного значення [2, 326] і переважно ототожнюється 3 розв'язанням проблем. Додамо, що творчість учня $\epsilon$ результатом пізнання, інтелектуального та емоційного розвитку.

За значенням творчості розрізняють чотири рівні: перший - результат творчості, новизни має значення для всього людства, другий - для великого кола людей, окремої країни, третій - для обмеженого кола, четвертий - значимий для самої людини $[8,97]$. Саме четвертий рівень (освітньотворча діяльність) характерний для учнів. Іноді, створюючи екологічний чи соціальний проект, досліджуючи краєзнавчу проблему та ін., учні можуть реалізувати й третій рівень, значимий для окремого регіону.

Реалізація творчого компоненту потребує розкриття його складників. Для розвитку творчості необхідні об'єктивні (соціальні та матеріальні) та суб' єктивні передумови (особисті якості-знання, вміння, мотивація, творчі якості). Значну роль відіграють розумові здібності (уява, інтуїція, неусвідомлені компоненти розумової активності) та їх якості - яскравість і уявність конкретних образів, швидкості комбінування інформації, що “дістається” з пам'яті, чи легкості виникнення здогадів, гіпотез, а також особистісні риси $[8,97]$.

Більшість дослідників розвиток творчості пов'язують із вирішенням проблемних завдань на етапах, визначених Я. Пономарьовим: 1) підготовчий (створення проблемної ситуації, постановка проблеми, їі аналіз); 2)натхнення або вирішення 
проблеми (активність підсвідомості); 3) творчий процес - інсайт (осяяння), якому передує стан спокою нервової системи; 4)рішення або упорядкування інтуїтивно отриманих результатів, встановлення логічного ланцюжка, що привів до відкриття [16, 54].

Зазначимо, що етап осяяння і передуючий йому стан заспокоєння потребують певного часу, переключення на іншу діяльність, а для кожного учня мисленнєві операції протікають із різною періодичністю. Це зумовлює розгляд проблемних завдань, значних за обсягом чи складністю, протягом цілого уроку, декількох уроків чи розділу. Учителю під час планування уроку слід підготувати завдання для переключення на іншу діяльність, оскільки під час їх реалізації із підсвідомості з'являються нові ідеї, розв'язок. Прийомами, які активізують продуктивне мислення, $\epsilon$ виокремлення протилежних властивостей, пошук аналогій, асоціювання понять, постановка питань, переформулювання, зміна альтернативи, комбінування та ін.

В. Моляко виділив стратегії творчості 3 використанням прийомів, виражених у зовнішніх діях: 1) засвоєння умов задачі (пошук аналогів, комбінації та ін.); 2) прийняття рішення про розуміння умов задачі на основі зовнішньо виражених суджень, дій суб'єкта; 3) організаційні дії суб'єкта; 4) прийняття рішення про можливу відповідність проекту (задумки, гіпотези) завданню за конкретними ознаками; 5) організаційні дії з апробації проекту (задумки, гіпотези) у вигляді пошуку аналогів, комбінацій та ін.; 6) цілісне прийняття рішення про відповідність проекту (задумки, гіпотези) вимогам завдання, яке визначило напрям пошуку структури 3 конкретними функціональними характеристиками $[9,186]$.

Автор приділив увагу аналізу процесу творчого сприйняття в умовах надмірного обсягу інформації або іiї дефіциту і виділив три складові стратегічного мислення як переплетіння інстинктивного і диспозиційного імпульсу: 1) реакція на нове (умову задачі); 2) інтуїтивний (ближній i дальній) прогноз можливостей асиміляції цього нового (принципової успішності чи неуспішності рішення задачі, проблеми); 3 ) підключення системи дій, прийомів, умінь доведення в конкретних умовах [9, 190].

Звернемо увагу на модель творчості, запропоновану М. Амосовим, яка являє собою розгортання узагальнених моделей в детальні [1, 158]. Здебільшого творець діє методом перебору: спускаючись по сходинках 3 верхнього рівня, перебирає вже наявні в його пам'яті моделі [1,
160]. Кожна вибрана модель перевіряється іншими критеріями узагальнення і складає другий рівень узагальнення. Кожна модель другого рівня перевіряється іншими критеріями і розгортається в модель третього рівня і т.д. Іншими словами використовується метод дедукції. Зрозуміло, що чим вищий рівень узагальнення, тим більша кількість моделей, які описують ціль $[1,162]$.

Засобами моделювання вчений вважає образне мислення та мовне, віддаючи перевагу першому [1, 124]. Мова дозволяє економно виражати складні образи, хоча й з втратою інформації $[1,128]$, але можемо зазначити, - $\epsilon$ засобом управління складністю і розвитку логічного мислення.

Адаптовано до проблемного уроку запропонована модель М. Амосовим буде виглядати наступним чином: формується ключова проблема, далі учні, аналізуючи їі, формують тематичні та змістові, що перевіряються використанням внутрішньокурсових та міжпредметних зв'язків. У такій моделі забезпечується системність навчання та креативність.

Розвитку образного мислення учнів сприяють ілюстрації. Досліджуючи методи роботи учнів 3 ілюстраціями, П. Мороз наголошує на важливості створення освітніх продуктів учнями. Для цього пропонує розглядати події та явища, відображені в ілюстрації, під різним кутом зору, очима учасників подій, явищ та сторонніх спостерігачів. У організації дослідження важливим є створення умов, за яких ініціатива переходить від учителя до учня $[10,7]$.

У нашій моделі конструювання творчого практичного заняття, яке починається 3 формування та аналізу проблемного завдання, використання ілюстрацій допомагає активізувати образне та мовленнєве мислення. Це також створює особливий настрій учнів та зумовлює “ситуацію успіху”. Зауважимо, що учасники можуть використати і метод індукції, розв’язуючи низку пізнавальних завдань i, узагальнюючи діяльність, отримують продукт пізнання. Це зумовлено реалізацією третього та четвертого рівнів творчості.

Виконуючи творчу роботу, учні мають володіти низкою прийомів, методів розв'язання проблемного завдання. Зауважимо, що пошук розв'язку завдання розгортається в підсвідомості, де вже мають бути сформовані прийоми та методи, опановані під час виконання вправ. Тому, під час комбінованих уроків варто урізноманітнювати діяльність учнів, збагачуючи їх досвід новими методами та прийомами. Серед 
засобів творчості мають бути образні та мовні ознаки практичних занять. Варто звернути увагу прийоми і методи мислення: “озвуч ілюстрацію”, “створи образ інформації” (у вигляді малюнку, схеми, моделі та ін.), “спостереження очевидного” (що бачать герої ілюстрації, особистісна характеристика), “подивись на світ чужими очима" та ін.

Одним із занять реалізації творчого компоненту компетентнісного навчання $€$ практичні заняття. Щоправда в дослідженнях предметів суспільствознавчої галузі можна зустріти й поняття практикуми, лабораторні заняття та лабораторно-практичні та ін. О. Певцова за методами вирізняє урок-лекція, урок-бесіда, диспут, лабораторне заняття 3 джерелами права $[11,126]$; О. Пометун, Г. Фрейман за формою організації навчальних занять називають лекцію, семінарське заняття, лабораторне заняття, практичне заняття [12, 239], які мають свою класифікацію.

32012 р. в програми історії та правознавства введені практичні заняття. Що ж таке практичні заняття? Зазначимо, що практичні завдання, спрямовані на формування вмінь та навичок, розвиток пізнання, учні виконують кожного уроку. У навчальних програмах практичні заняття $\epsilon$ окремим уроком теми і здебільшого розміщені у кінці кожної теми, що створює можливість набути досвід комплексного застосування та вдосконалення компетенцій. У навчальній програмі 3 основ правознавства практичні заняття визначаються уроками застосування знань, що мають допомогти сформувати уявлення про тему, $\epsilon$ самостійною роботою учнів над конкретними аспектами змісту теми з використанням різних джерел знань.

У навчальних програмах з історії в організації практичних занять надається свобода: можуть відбуватися як за бажанням вчителя, так і учнів, як під час уроку, так і вдома. Важлива динаміка практичних занять: 3 кожним наступним класом збільшується обсяг, складність, характер (від описових до аналітичних), види джерел та способи виконання, ступінь самостійності. Старшокласники самостійно планують методи та способи досягнення мети.

Але таке пояснення поняття практичні заняття не дозволяє вирізнити їх 3-поміж інших уроків, бо систему знань про тему ми формуємо на кожному уроці, активізуючи знання та вміння, знаходячи зв'язки між поняттями, подіями, явищами та ін. I самостійній роботі теж приділяється увага, як під час уроку, так і вдома.

Зазначене вище, аналіз досліджень проблеми та педагогічний досвід дозволяють визначити на значимість предметних компетентностей, які розвиватимуться або реалізовуватимуться на практиці: у практичних ситуаціях, проблемних та дослідницьких завданнях, пов'язаних з життєвим досвідом учнів. Аналіз історичних джерел із проекцією їх наслідків у сьогодення та майбутнє, положень нормативно-правових актів та їх використання під час розв'язання проблемних життєвих чи навчальних ситуацій, власній життєдіяльності, створенні навчальних правил, проектів та ін. сприяє поєднанню теорії та практики, усвідомленню теоретичних та практичних аспектів навчання, розвитку творчого мислення.

Дослідники розглядають поняття 3 дидактичного дискурсу та методичного. 3 дидактичного - це форма навчального заняття, організована педагогом, що передбачає детальний розгляд учнями теоретичних положень шляхом застосування набутих знань та сформованих умінь і навичок [2, 268]. Більшим за обсягом, але вужчим за змістом є визначення поняття практичні заняття, як форма навчання, під час якого на основі раніше отриманих знань та сформованих умінь, школярі розв'язують пізнавальні задачі, презентують результати своєї творчої діяльності чи опановують більш складні пізнавальні вміння вивчення предмета [5, 305]. К. Баханов визначає лабораторно-практичні заняття з історії як засіб набуття знань із джерел, статистичних даних 3 метою на конкретних фактах розкрити закономірності розвитку суспільства [3, 87], акцентуючи увагу на дослідницькому їх характері.

О. Пометун, Г. Фреймут вирізняють практичне заняття 3-поміж інших форм навчання спрямованістю: застосовувати отриманні знання та вміння в нових навчальних ситуаціях $[12,251]$. Зазначимо, що нова навчальна ситуація, нестандартні умови зумовлюють пошук нових способів пізнання, а у розв'язанні проблем переструктурування елементів відомого способу.

В. Власов під час практичних занять акцент у пізнавальній діяльності переносить 3 когнітивного компоненту на діяльнісно-практичний, а саме самостійну творчо-пошукову діяльність учня, спрямовану на формування предметних умінь та розвиток критичного мислення. Формою проведення практичних занять на основному етапі має бути письмова робота учнів, яка дозволяє коротко викласти власні думки й оцінити учнів [4, 17]. Ю. Малієнко зосереджує увагу на особистісно-орієнтованому компоненті: урізноманітненні форм та засобів роботи (в 
групах, індивідуально, робота 3 джерелами та ін.), які мають мотивувати учня [7, 44].

T. Ремех пов'язує практичні заняття 3 правознавства з розвитком компетентності учнів - поглиблення, розширення, деталізація теоретичних правових знань учнів, розвиток їхнього наукового мислення, юридичної логіки та мови, формування і удосконалення предметних умінь [13, 43], а отже, і вищим рівнем пізнання. Л. Рябовол характеризує практичне заняття як компетентнісно орієнтоване і розкриває його структуру: наявність спрямованого способу діяльності (доведіть, обгрунтуйте, дайте визначення, зробіть аналіз, дайте юридичну оцінку, порівняйте, встановіть види, підстави тощо), змісту завдання для розв'язку (умови або зміст події, явища, процесу, ситуації державно-правової дійсності), а також джерела інформації необхідних для аналізу чи вирішення завдання (текст підручника, джерела права, безпосередньо нормативно-правові акти, усні свідчення, набуті раніше знання учнів, уміння) [14, 296].

Таким чином, у зміст поняття закладається розвивальна мета навчання, вищий рівень пізнання: поглиблення пізнавальної діяльності у К. Баханова, С. Гончаренка, розвиток компетенцій T. Ремех, Т. Рябовол та творчо-пізнавальної діяльності уВ. Власова, С. Вяземського, О. Стрелової, О. Пометун, Г. Фреймут та ін.

Звернемо увагу, що урок практичного заняття можна визначити як лабораторію або майстерню (що в переносному значенні тлумачиться як внугрішні творчі процеси, внугрішня діяльність когонебудь, чого-небудь), опанування вищого рівня умінь та навичок учнів, а також творчого способу застосування сформованих умінь та навичок у прочесі навчально-пізнавальної діяльності, нової навчальної ситуації. Тому практичні заняття визначаємо як майстерню для розвитку творчих здібностей учнів.

Зауважимо, що творча робота характеризується більшим ступенем самостійності (свободи учня) та подальшим розвитком, вдосконаленням, збагаченням умінь та навичок, а також формуванням оригінального способу їх застосування під час пізнавальної чи дослідницької роботи. Якщо під час комбінованого уроку учні опановували вміння та навички, формували спосіб їх застосування, то під час практичних занять - вони досягають майстерності навчання. Практична складова навчання 3 орієнтацією на розвиток творчих здібностей сприятиме ефективності навчання, розвиткугнучкості мислення, генеруванню нових ідей, задумів, способів розв'язання завдань.
Узагальнюючи, можемо визначити ознаки практичних занять: 1) спрямовані на вдосконалення і розвиток опанованих умінь та навичок, способів діяльності у нових ситуаціях; 2) забезпечують системність знань, умінь та навичок теми; 3) мають творчо-пізнавальний характер завдань та проблем; 4) пов'язані 3 навчальним та життєвим досвідом; 5) характеризуються значним ступенем самостійної роботи учнів; 6) зумовлюють консультуючу та координаційну функції вчителя у спільній діяльності класу; 7) мотивування учнів забезпечуються використанням різних джерел, урізноманітненням методів та форм роботи.

Варіативність змісту практичних занять (практикумів) свідчить проїх класифікацію (табл. 1). О. Пометун, Г. Фрейман розрізнять практикуми: 1)розвитку пізнавальних умінь (організований на початку тематичного блоку); 2) розв'язання пізнавальних задач (як спосіб повторення, систематизації та практичного застосування нових знань, умінь та навичок через розв'язання завдань переважно наприкінці тематичного блоку); 3 ) перевірки творчо-пошукової діяльності (представлення рефератів, наукових доповідей, розв'язку тематичної предметної проблеми, складені за допомогою персоніфікації, драматизації, стилізації, підготовлені на основі краєзнавчих музеїв, регіональних архівів); 4) підсумків проекту [12, 239].

К. Баханов класифікує лабораторно-практичні заняття за формуванням окремих предметних історичних умінь роботи з джерелами: 1 ) писемними джерелами (літописними повідомленнями, законодавчими актами); 2)статистичними даними; 3) історичними картами; 4) речовими (фотографії, муляжі) та усними джерелами; 5) матеріалами періодичної преси [3,87].

T. Рябовол пропонує проводити практичні заняття з правознавства за дидактичною метою: вивчення нового матеріалу та повторювальноузагальнювальні [14, 296], Т.Ремех до такої класифікації пропонує й юридичні практикуми [13, 47]. За методами проведення творчі практичні заняття розрізняють: неімітаційні (дискусії, екскурсії, виїзні заняття), імітаційні неігрові (аналіз конкретних ситуацій або документації), імітаційні ділові, рольові ігри, ігрове проектування тощо [6, 72] .

Зауважимо, що реалізувати творчий компонент практичних занять доцільно з використання евристичного методу (в основі якого пізнавальна суперечність між теоретично можливим способом вирішення проблеми високого рівня та невідомим способом їі розв’язання i використовується у випадку значного обсягу навчального матеріалу). 
Класифікація практичних занять за дидактичною метою

\begin{tabular}{|c|c|c|c|c|c|}
\hline Види & \multicolumn{4}{|c|}{ Пізнавальні } & Повторювально- \\
\hline $\begin{array}{l}\text { Види } \\
\text { практич } \\
\text {-них } \\
\text { занять }\end{array}$ & \multicolumn{2}{|c|}{$\begin{array}{l}\text { Практикуми з розв’язання } \\
\text { пізнавальних завдань }\end{array}$} & \multicolumn{2}{|c|}{$\begin{array}{l}\text { Вивчення нового матеріалу, виконання } \\
\text { нескладних завдань, розвитку } \\
\text { пізнавальних умінь }\end{array}$} & $\begin{array}{l}\text { Комплексне } \\
\text { застосування, } \\
\text { поглиблення, } \\
\text { узагальнення, } \\
\text { систематизація } \\
\text { знань, умінь, } \\
\text { навичок }\end{array}$ \\
\hline Автор & О. Пометун & К. Баханов & Л. Рябовол & В. Власов, В. Гісем & \\
\hline Етапи & $\begin{array}{l}\text { 1) організацій- } \\
\text { ний } \\
\text { (оголошується } \\
\text { тема заняття, } \\
\text { завдання, умови і } \\
\text { способи } \\
\text { проведення, } \\
\text { форми роботи } \\
\text { учнів; } \\
\text { 2) розв’язання } \\
\text { пізнавальних } \\
\text { завдань (спочатку } \\
\text { колективно за } \\
\text { допомогою } \\
\text { пам’ятки, а далі } \\
\text { самостійно чи в } \\
\text { групах; } \\
\text { 3) обговорення } \\
\text { готових рішень; } \\
\text { 4) підведення } \\
\text { підсумків. } \\
\text { [12, 252] }\end{array}$ & $\begin{array}{l}\text { 1)сприйняття } \\
\text { мети; } \\
\text { 2) пошук в } \\
\text { історичних } \\
\text { джерелах; } \\
\text { 3)систематиза } \\
\text { ція і } \\
\text { узагальнення } \\
\text { даних і на } \\
\text { основі цього } \\
\text { 4) висунення } \\
\text { гіпотези; } \\
\text { 5) пошук } \\
\text { доказів } \\
\text { (можливе як } \\
\text { домашнє } \\
\text { завдання) } \\
\text { [3, 87] }\end{array}$ & $\begin{array}{l}\text { 1) вивчення } \\
\text { нового } \\
\text { матеріалу з } \\
\text { використанням } \\
\text { різних джерел } \\
\text { правової } \\
\text { інформації, } \\
\text { 2) обговорення } \\
\text { можливостей } \\
\text { застосування } \\
\text { матеріалу } \\
\text { (поняття); } \\
\text { 3) постановка } \\
\text { проблеми чи } \\
\text { формулювання } \\
\text { вчителем } \\
\text { завдання (задачі, } \\
\text { ситуації, що } \\
\text { потребує } \\
\text { юридичного } \\
\text { аналізу); } \\
\text { 4) складання } \\
\text { плану чи моделі } \\
\text { виконання } \\
\text { завдання } \\
\text { (подумки); } \\
\text { 5) практичне } \\
\text { виконання } \\
\text { завдання } \\
\text { (спираючись на } \\
\text { знайдені в } \\
\text { джерелах } \\
\text { правової } \\
\text { інформації [14, } \\
\text { 296] }\end{array}$ & $\begin{array}{l}\text { 1) підготовчий } \\
\text { (повторення та } \\
\text { узагальнення } \\
\text { фактів і понять } \\
\text { необхідних для } \\
\text { засвоєння нового } \\
\text { матеріалу; } \\
\text { 2) основний } \\
\text { (засвоєння нових } \\
\text { знань, формування } \\
\text { умінь); } \\
\text { а) оголошення } \\
\text { теми та визначення } \\
\text { навчальних цілей, } \\
\text { обговорення } \\
\text { мотиваційних } \\
\text { завдань/запитань } \\
\text { б) вивчення } \\
\text { навчального } \\
\text { матеріалу } \\
\text { (сприймання } \\
\text { осмислення - } \\
\text { завдання та } \\
\text { запитання для } \\
\text { засвоєння - } \\
\text { формування та } \\
\text { вдосконалення } \\
\text { вмінь (здійснюється } \\
\text { письмово) } \\
\text { 3)3авершальний } \\
\text { (контроль } \\
\text { навчальних } \\
\text { досягнень, широке } \\
\text { узагальнення, само } \\
\text { або } \\
\text { взаємооцінювання) } \\
\text { [4, 17-18] }\end{array}$ & $\begin{array}{l}\text { 1) постановка } \\
\text { проблеми, } \\
\text { формулювання } \\
\text { учнем/вчителем } \\
\text { завдання (задачі, } \\
\text { ситуації, яка } \\
\text { потребує } \\
\text { юридичного } \\
\text { аналізу); } \\
\text { 2) обговорення } \\
\text { способів } \\
\text { розв'язання } \\
\text { (встановлення } \\
\text { нормативно- } \\
\text { правового акта та } \\
\text { правової норми, } \\
\text { що є підставою } \\
\text { розв'язання } \\
\text { проблеми, задачі, } \\
\text { аналізу ситуації); } \\
\text { 3) складання } \\
\text { плану (моделі) } \\
\text { роботи } \\
\text { 4) виконання } \\
\text { завдання кожним } \\
\text { учнем (у супроводі } \\
\text { вчителя); } \\
\text { 5) встановлення } \\
\text { результатів та їх } \\
\text { аналіз (можлива } \\
\text { теоретична } \\
\text { інтерпретація } \\
\text { результатів); } \\
\text { 6) оцінка }\end{array}$ \\
\hline $\begin{array}{l}\text { Місце в } \\
\text { навчаль } \\
\text {-ному } \\
\text { плані }\end{array}$ & $\begin{array}{l}\text { Вступний урок } \\
\text { або наприкінці } \\
\text { тематичного } \\
\text { блоку }\end{array}$ & $\begin{array}{l}\text { Може бути } \\
\text { окремим } \\
\text { елементом } \\
\text { уроку, } \\
\text { окремим } \\
\text { заняттям, } \\
\text { спареними } \\
\text { уроками }\end{array}$ & $\begin{array}{l}\text { Як окремий урог } \\
\text { теми розділу }\end{array}$ & тягом вивчення & $\begin{array}{l}\text { Завершальний } \\
\text { етап вивчення } \\
\text { теми, розділу }\end{array}$ \\
\hline
\end{tabular}

Узагальнюючи етапи практичних занять, ma їx зміст: вступна (організаційний момент, запропоновані дослідниками, адаптуючи їх до актуалізація навчального і життєвого досвіду, етапів творчості, визначаємо ключові частини формулювання проблеми, гіпотези (система 
суджень, понять, умовиводів, в основі якої проблемні судження), цілей, мети, складання плану (тематичних та змістових проблем), вибір способів досягнення цілей)), основна (творчопошукова діяльність, розв'язування завдань/ проблеми, моделювання способу(ів) розв'язання) і заключна (представлення та аналіз результатів, оцінювання/самооцінювання).

У залежності від цілей, вибору методів (проблемного, проекту, ігрового, голографічного та ін.) практичного заняття зміст частин може змінюватися (доповнюватися чи звужуватися) (табл.2). Зауважимо, що частини практичного заняття можуть реалізуватися цілісно впродовж уроку, або ж вступна частина - на початку нового розділу, а інші дві - під час практичного заняття наприкінці розділу, що залежить від ступеня узагальнення проблемного завдання.

Під час практичних занять із значним ступенем свободи творчо-пізнавальної роботи учнів змінюються характер діяльності вчителя, який здійснює координуючу та консультуючу функції спільної діяльності класу, а підготовка до занять потребує творчого підходу. Рекомендації навчальних програм дозволяють самостійно визначити тему практичного заняття і його місце у темі. У процесі підготовки до уроку учитель розширює тематику уроку, визначеною

Таблиця 2.

Порівняльна характеристика моделей комбінованого уроку та практичного заняття

\begin{tabular}{|c|c|}
\hline КОМБІНОВАНИЙ УРОК & ПРАКТИЧНІ ЗАНЯТТЯ \\
\hline \multicolumn{2}{|c|}{ META } \\
\hline $\begin{array}{l}\text { Формування життєвих та предметних } \\
\text { компетенцій } \\
\text { Опанування репродуктивними, } \\
\text { перетворювальними та творчими уміннями } \\
\text { Практичне застосування використання } \\
\text { сформованих умінь та навичок під час } \\
\text { розв’язання навчальних завдань }\end{array}$ & $\begin{array}{l}\text { Набуття досвіду реалізації предметних та } \\
\text { міжпредметних компетенцій } \\
\text { Розширення сфери пізнавальної діяльності } \\
\text { Розвиток та вдосконалення умінь та навичок, } \\
\text { набуття досвіду системного використання } \\
\text { сформованих умінь та навичок } \\
\text { Формування оригінального способу застосування } \\
\text { копметенцій у нових ситуаціях } \\
\text { Особистісний розвиток учня }\end{array}$ \\
\hline \multicolumn{2}{|c|}{ ПРОЦЕС } \\
\hline Навчально-пізнавальна діяльність & $\begin{array}{l}\text { Творчо-пізнавальна та дослідницька діяльність, } \\
\text { інтегроване навчання }\end{array}$ \\
\hline \multicolumn{2}{|c|}{ ЕТАПИ } \\
\hline $\begin{array}{l}\text { Вступна частина: мотивація учнів, } \\
\text { актуалізація навчального і життєвого досвіду, } \\
\text { формування мети уроку } \\
\text { Основна частина: навчально-пізнавальна } \\
\text { діяльність, формування компетенцій, } \\
\text { виконання практичних завдань, опанування } \\
\text { вміннями та навичками та їх застосування } \\
\text { Заключна частина: узагальнення та } \\
\text { систематизація знань, умінь та навичок, } \\
\text { аналіз результатів, оцінювання діяльності, } \\
\text { домашнє завдання }\end{array}$ & $\begin{array}{l}\text { Вступна частина: організаційний момент, } \\
\text { актуалізація навчального і життєвого досвіду, } \\
\text { формулювання проблем, гіпотези, цілей, мети, } \\
\text { складання плану, вибір способів досягнення цілей } \\
\text { Основна частина: творчо-пошукова діяльність, } \\
\text { розв'язування системи завдань/проблеми } \\
\text { (ключового, тематичних та змістових питань), } \\
\text { формування оригінального способу дій } \\
\text { Заключна частина: представлення та аналіз } \\
\text { результатів, оцінювання/самооцінювання }\end{array}$ \\
\hline \multicolumn{2}{|c|}{ ПЕРЕВАЖАЮЧІ МЕТОДИ ТА ФОРМИ } \\
\hline $\begin{array}{l}\text { Широкий спектр методів (пояснення, бесіда, } \\
\text { ігрові) та форм навчання (усна та письмова) }\end{array}$ & $\begin{array}{l}\text { Активні та інтерактивні. Проект, проблемні, } \\
\text { дослідження, анкетування, експеримент, евристичні, } \\
\text { моделювання ситуації та ін. Переважаюча письмова } \\
\text { форма }\end{array}$ \\
\hline \multicolumn{2}{|c|}{ ВЗАЕМОДІЯ ВЧИТЕЛЯ ТА УЧНІВ } \\
\hline $\begin{array}{l}\text { Ведуча навчальна функція вчителя, поступове } \\
\text { зростання ступеня самостійності учня }\end{array}$ & $\begin{array}{l}\text { Більший ступінь самостійності учня/учнів, розвиток } \\
\text { їх ініціативності, координуюча та консультуюча } \\
\text { функції вчителя, спільна діяльність вчителя та учнів }\end{array}$ \\
\hline \multicolumn{2}{|c|}{ РЕЗУЛЬТАТ } \\
\hline $\begin{array}{l}\text { Засвоєні знання, вміння та навички, способу } \\
\text { діяльності, застосування під час розв’язання } \\
\text { завдань з можливістю використання в житті }\end{array}$ & $\begin{array}{l}\text { Опанування системою знань та вмінь, способів } \\
\text { діяльності у вигляді завершеного продукту творчо- } \\
\text { пізнавальної діяльності. Реалізація пізнавальних } \\
\text { інтересів, творчих здібностей }\end{array}$ \\
\hline
\end{tabular}




\section{ПРАКТИЧНІЗАНЯТТЯ ЗСУСПІЛЬСТВОЗНАВСТВА-ТВОРЧА МАЙСТЕРНЯ КОМПЕТЕНТНОГО УЧНЯ}

програмою, розробляє інструкцію та завдання для практичних робіт, добирає форми і методи, джерела роботи.

Творчий підхід учнів до виконання завдань створює умови, в яких учитель спільно із учнями стає учасником навчально-пізнавального процесу. Спосіб дослідження окремої проблеми учнями може бути оригінальним, а зміст - виходити за межі навчального матеріалу. Зміст творчих завдань має бути відкритим, спонукати до подальшої пізнавальної діяльності, формування нового способу пізнання. Таким чином, елемент оригінальності, нестандартності створює умови для непередбачуваності процесу творчого виконання завдання й активізує пізнавальну діяльність його учасників.

Методами проведення практичних занять $\epsilon$ евристичні, проект, ситуативне моделювання, імітаційні (аналізу чи розв'язання проблемних ситуацій, дилем), експеримент, кейс-метод, аналогії, голографічні та ін. Засобами розв'язування творчих завдань можуть бути міжпредметні зв'язки суспільствознавчих предметів (з географією, українською мовою та літературою, зарубіжною літературою, біологією, економікою та ін.). Останні в методичних рекомендаціях 2018 - 2019 рр. виділені окремою коміркою.

Особливу увагу вчитель приділяє формі виконанню творчих завдань. Це можуть бути створення презентації чи малюнка, написання статті у вікіпедію з дослідницької проблеми, розроблення збірника правил, створення допису у газету минулого чи сьогодення, віртуальна чи уявна мандрівка, розроблення пам'ятки, створення родоводу (наприклад, грецьких богів), розроблення квест-карти з окремої теми, організації круглого столу, дискусії чи диспугу та ін.

Висновки дослідження і перспективи подальших розвідок. Таким чином, особистісно-зорієнтоване та компетентнісне навчання для успішної життєдіяльності учнів потребує розвитку творчості. Під час навчання суспільствознавчих предметів в учнів розвиваються понятійне мислення, вміння аналізувати події та явища, життєві та навчальні ситуації. Творчий розвиток особистості характеризується гнучкістю, глибиною та широтою мислення, знаходженням оригінальних способів розв'язання проблем. У цьому процесі важливо розвивати емоційне та логічне мислення, уяву, фантазію, а відтак використовувати міжпредметні зв'язки, образні та словесні засоби навчання. Урізноманітнення методів, прийомів, засобів навчання сприяє мотивації учнів.
Важливе місце у освітньому процесі, що зумовлює розвиток творчості компетентного учня, належить практичним заняттям. Це освітня майстерня вдосконалення опанованих умінь та навичок, збагачення набутого досвіду оригінальними способами розв'язання системи проблем у процесі творчо-пізнавальної діяльності.

Етапна модель практичного заняття передбачає створення проблемної ситуації, формулювання ключової, тематичних та змістових проблем, актуалізацію опорних знань та вмінь, формулювання гіпотези, цілей, мети, складання плану, вибір способів досягнення цілей (вступна частина), творчо-пошукову діяльність, розв'язування системи завдань/проблеми, формування оригінального способу дій (основна частина) та представлення і аналіз результатів, оцінювання/самооцінювання (заключна частина). Цілісна реалізація частин заняття залежить від ступеня узагальнення проблеми. Розв'язання значної за ступенем узагальнення проблеми доцільно розпочинати на початку розділу і реалізувати вступну частину, а основну та заключну - безпосередньо під час практичного заняття.

Творча діяльність учнів, значний ступінь свободи та ініціативності зумовлює координуючу та консультуючу функції вчителя у спільній діяльності класу та характеризується творчим підходом до організації заняття, створення динамічної інструкції його проведення.

Подальшого дослідження потребує розроблення творчих завдань, методів розвитку творчості учнів на етапах практичного заняття, критеріїв оцінювання творчих завдань, уроків 3 реалізацією моделі практичного заняття як творчої майстерні компетентного учня.

\section{ЛIТЕРАТУРА}

1. Амосов Н.М. Алгоритмы разума / Н.М. Амосов. -К.: Наукова думка, 1979. -223 с.

2. Гончаренко С.У. Український педагогічний словник / С. Гончаренко. -К., 1997. - 376с.

3. Баханов К.О. Лабораторно-практичні роботи 3 історії в середній школі / К.О. Баханов // Український історичний журнал. - 1991. - № 4. - С. 86-93.

4. Власов В. С. Методика проведення практичних занять у 6 класі / В.Власов//Історія і суспільствознавство в школахУкраїни: теорія іметодика навчання. - 2014. № 9. - С. $16-35$.

5. Вяземский Е.Е., Стрелова О.Ю. Теория и методика преподавания истории / Е.Е.Вяземский, О.Ю. Стрелова. - М.: Владос. $-2003 .-384$ с.

6. Інструктивно-методичні рекомендації щодо вивчення в закладах загальної середньої освіти навчальних предметів та організації освітнього процесу у 2018/2019 н.р. Додаток до листа Міністерства освіти і 


\section{ПРАКТИЧНІЗАНЯТТЯ ЗСУСПІЛСТВОЗНАВСТВА-ТВОРЧА МАЙСТЕРНЯ КОМПЕТЕНТНОГО УЧНЯ}

науки України від 03.07.2018p. №1/9-415 [Електронний ресурс] / Міністерство освіти і науки України // - Режим доступа: https://mon.gov.ua/ua/osvita/zagalna-serednyaosvita/metodichni-rekomendaciyi

7. Малієнко Ю.Б. Практичні заняття в системі історичної освіти основної школи: методичний коментар до програми 2012 року з історії для основної школи / Ю.Б.Малієнко // Історія і суспільствознавство в школах України: теорія і методика навчання. - 2013. - № 5 -6. C. $42-47$.

8. Мамчук Л.П. Творчість та творчі здібності особистості у сучасній психології [Електронний ресурс] / Л.П. Мамчук, В.М. Ямницький // Психологія: реальність і перспективи: зб. наук. пр. Рівн. держ. гуманіт. ун-т. - 2014. - Вип. 3. - С. 96 - 100. - Режим доступа: http://nbuv.gov.ua/UJRN/prp_2014_3_31

9. Моляко В.О. Информационные индикаторы одаренности / В.О. Моляко // Обдаровані діти інтелектуальний потенціал держави: матеріали Міжнародної науково-практичної конференції, 2 - 8 липня 2018 р., м.Чорноморськ, Одеська обл. - К.: Інститут обдарованої дитини НАПН України, 2018. C. $184-194$.

10. Мороз П. В. Методика розвитку в школярів вміння бачити проблеми засобами ілюстрацій підручника історії стародавнього світу/П.В.Мороз // Проблеми сучасного підручника: зб. наук. пр. / Ін-т педагогіки АПН України. - К.: Педагогічна думка, 2010. - Вип. 10. - С. $482-493$.

11. Певцова Е. А. Теория и методика обучения праву: Учеб. / Е.А. Певцова. - М.: Владос, 2002. - 459 с.

12. Пометун О.І. Методика навчання історії в школі / О.І. Пометун, Г. О. Фрейман. - К.: Генеза, 2006. - 328 с.

13. Ремех Т.О. Практичні заняття $з$ правознавства: методичний аспект / Т.О. Ремех // Український педагогічний журнал. - 2016. - № 4. - С. 43 - 51.

14. Рябовол Л.Т. Особливості уроку як форми організації компетентнісного навчання правознавства / Л.Т. Рябовол // Наукові записки. - Випуск 132. - Серія: Педагогічні науки. - Кіровоград: РВВ КДПУ ім. В.Винниченка, 2014. -С. 293-297.

15. Савченко О. Ключові компетентності інноваційний результат шкільної освіти / О. Савченко / / Рідна школа. - 2011. - № 8-9. - С. 4 - 8 .

16. Туриніна О.Л. Психологія творчості: навч. посіб. / О.Л. Туриніна. - К.: МАУП, 2007. - 160 с.

17. Філософський енциклопедичний словник / НАН України, Ін-т філософії імені Г.С. Сковороди; [редкол.: В. І. Шинкарук (голова) та ін.]. - Київ: Абрис, 2002. - 742 с.

\section{REFERENCES}

1. Amosov, N. M. (1979). Algoritmy razuma [Algorithms of mind]. Kyiv: Naukova dumka, 223 p. [in Russian].

2. Ghoncharenko, S. U. (1997). Ukrajinsjkyj pedaghoghichnyj slovnyk [Ukrainian Pedagogical Dictionary]. Kyiv: Lybidj, 376 p. [in Ukrainian].

3. Bakhanov, K. O. (1991). Laboratorno-praktychni roboty $\mathrm{z}$ istoriji $\mathrm{v}$ serednij shkoli [Practical laboratory exercise designed in the school]. Ukrainian history journal, 4. pp. 86-93. [in Ukrainian].
4. Vlasov V. S. (20014). Metodyka provedennja praktychnykh zanjatj u 6 klasi [Metodology the holding of practical exsercises]. History and social studies in the school Ukrainian: theory and methodology of teaching, no.9, pp.16-35. [in Ukrainian].

5. Vjazemskij, E. E. \& Strelova, O. Ju. (2003). Teorija $i$ metodika prepodavanija istorii [The theory and methodology of teaching history]. Moscov: Vlados, $384 \mathrm{p}$. [in Russian].

6. Instruktyvno-metodychni rekomendaciji shhodo vyvchennja $\mathrm{v}$ zakladakh zaghaljnoji serednjoji osvity navchaljnykh predmetiv ta orghanizaciji osvitnjogho procesu u 2018/2019 n.r. [Instructive-methodological recommendations of education in general secondary education establishments and the organization of the educational process on 2018 - 2019]. Ministry of Education and Science of Ukraine, 03.07.2018. Available at: https://mon.gov.ua/ua/osvita/zagalna-serednyaosvita/metodichni-rekomendaciyi [in Ukrainian].

7. Malijenko, Ju. B. (2013). Praktychni zanjattja v systemi istorychnoji osvity osnovnoji shkoly: metodychnyj komentar do proghramy 2012 roku z istoriji dlja osnovnoji shkoly [Practical exercises in system historical education of the basic school: methodological comment to program 2012 of history for basic school]. History and social studies in Ukrainian school: theory and methodology of teaching, no.5-6, pp. 42-47. [in Ukrainian].

8. Mamchuk, L. P. (2014). Tvorchistj ta tvorchi zdibnosti osobystosti u suchasnij psykhologhiji [Creativity and creative skills of the individual in modern psychology]. Realities and Prospects: zb. nauk. pr. Available at: http:/ /nbuv.gov.ua/UJRN/prp_2014_3_31, vol.3,pp.96-100. [in Ukrainian]

9. Moljako, V. O. (2018). Informatsionnye indikatory odarennosti [Information indicators of the gifts]. Obdarovani dity - intelektualnyi potentsial derzhavy: materialy Mizhnarodnoi naukovo-praktychnoi konferentsii, 2-8 lypnia 2018 r., m.Chornomorsk, Odeska $o b l$. - Gifted children are intellectual potential of state. Proceedings of the All Ukrainian Scientific and Practical Conference. (pp. 184-194). Kyiv: Institute of gifted NAPNU. [in Ukrainian].

10. Moroz, P. V. (2010). Metodyka rozvytku v shkoljariv vminnja bachyty problemy zasobamy iljustracij pidruchnyka istoriji starodavnjogho svitu [Methodology of the development in students of the skill to see of the problem]. Challenges of the modern of texstbook: Institute of Education Sciences, Kyiv: Pedaghoghichna dumka,vol. 10, pp. 482-493. [in Ukrainian].

11. Pevcova, E. A. (2002). Teorija i metodika obuchenija pravu: Ucheb. [The theory and methodology of teaching law: textbook]. Moscov: Vlados, 459 p. [in Russian].

12. Pometun, O. I. \& Freiman, H. O. (2016). Metodyka navchannja istoriji $v$ shkoli [Teaching methodology history in the school]. Kyiv: Gheneza, 328 p. [in Ukrainian].

13. Remekh, T.O. (2016). Praktychni zanjattja $z$ pravoznavstva: metodychnyj aspekt [Practical exercises on law]. Ukrainian pedagogical journal, no.4, pp. 43-51. [in Ukrainian]. 


\section{ЯКЩО МАТЕМАТИКА-ТОЗГУМОРОМ: НЕТРАДИЦЙНІ ПШДХОДИ ДО ВИКЛАДАННЯ МАТЕМАТИКИ У ВИЩЙ ШКОЛІ}

14. Rjabovol, L. T. (2014). Osoblyvosti uroku jak formy orghanizaciji kompetentnisnogho navchannja pravoznavstva [Espesially of the lesson as form of organization by competent training of law]. Scientific notes, vol. 132, Kirovoghrad: RVV KDPU im. V.Vynnychenka, pp.293-297. [in Ukrainian].

15. Savchenko, O. (2011). Kljuchovi kompetentnostiinnovacijnyj rezuljtat shkiljnoji osvity [Key competencies are an innovative result of school education]. Native school, no.8-9, pp. 4-8. [in Ukrainian].

16. Turynina, O.L. (2007). Psykhologhija tvorchosti: navch. posib. [Psychology of creativity: training manual]. Kyiv: MAUP, 160 p. [in Ukrainian].

17. Filosofsjkyj encyklopedychnyj slovnyk (2002). [Philosophical encyclopedic dictionary]. Kyiv: Abrys, 742 p. [in Ukrainian].

Стаття надійшла до редакції 15.09.2018

\section{УДК 378.016:51:82-7}

DOI:

Олександр Кошелєв, кандидат педагогічних наук, дочент кафедри природничоматематичних дисииплін та інформатики в початковій освіті ДВНЗ “Донбаський держаний педагогічний університет”"

Валерій Сиротенко, кандидат філологічних наук, доиент кафедри теорії і практики початкової освіти ДВНЗ “Донбаський держаний педагогічний університет”

\section{ЯКЩО МАТЕМАТИКА - ТО З ГУМОРОМ: НЕТРАДИЦІЙНІ ПІДХОДИ ДО ВИКЛАДАННЯ МАТЕМАТИКИ У ВИЩІЙ ШКОЛІ}

Стаття присвячена проблемі, як змінити атмосферу в студентській аудиторії, щоб вона стала ненав'язливою, позбавилася рутинності, сухої офіційності, а натомість запанували психологічноінтелектуальна розкутість, креативність не лише в підходах до викладання різноманітного математичного матеріалу, а, пери за все, у взасминах між викладачем і студентами, між одногрупниками. Засобом, який здатен реалізувати проголошені наміри, виступає гумор. Він повинен панувати і при подачі теоретичного матеріалу, $і$ в ситуачї наростання психологічного конфлікту, $і$ як засіб зняття психолого-інтелектуального навантаження. Ураховуючи ж дидактичний характер завдань, гумористичне наснаження заняття вибудовується на трунті каламбуру, гротескового жарту, іронічного зауваження, карикатурного зображення, щяо й обумовлює бажаний ефект.

Ключові слова: гумор; іронія, гротеск; каламбур; жарт; карикатура; круги Ейлера; пропориія; графік функиій; “золотий переріз”.

Puc. 3. Лim. 12.

Oleksandr Koshelyev, Ph.D.(Pedagogy), Associate Professor State Highter Educational Establishment "Donbas State Pedagogical University"

Valeriy Syrotenko, Ph.D.(Philology), Associate Professor State Highter Educational Establishment "Donbas State Pedagogical University"

\section{IF IT'S MATHEMATICS - IT SHOULD BE HUMOROUS: NON-TRADITIONAL APPROACHES TO TEACHING MATHEMATICS AT TERTIARY INSTITUTIONS}

The article is devoted to the issue of changing the atmosphere of the students' audience to make it unobtrusive, to get rid of routine and restrained formality, on the other side, psychological and intellectual freedom and creativity should prevail not only among the approaches to teaching various math materials, but also in relationships between a teacher and students, between groupmates. The means, which can implement the mentioned intends, is humour. The drollery and humour as its direct manifestation are based on paradoxical thinking; non-traditional approach to things, so mathematics requires namely them, as the successful mastering of its "secrets" necessarily provides daring thoughts, looking for non-traditional ways of solving any math problems, ability to combine externally noninterconnected elements to find their essence.

Making humorous situation, while presenting lecture materials or conducting practical workshops, increases the emotional tone of classes, facilitates the perception and awareness of math knowledge due to the pun-based and humorous form of its presentation (the point about the role of Euler circles while studying geometric circuits makes its understanding more accessible if one tries to imagine them before "Euler's eyes").

Addressing to humorous tasks (their content is based on the principle of grotesque) can be appropriate when drawing function schedules is carried out through comprehension of the phrase: "Love is a curved line that is going through the heart, costs the packet and finally goes sideways!"

Humour is also useful for avoiding psychological conflicts. So the story about J. Danzig, who managed to 